\title{
ACRL Membership Meeting
}

\section{ANNUAL CONFERENCE CHICAGO, ILLINOIS}

Monday, June 26, 1972-2:30 P.M.

The meeting was called to order by President Joseph H. Reason, presiding officer. Mr. Reason first expressed the Association's thanks to the headquarters office staff for their splendid work during a trying year. He also thanked the members of the Local Arrangements Committee for their efforts in making the ACRL Exhibit Booth a particularly outstanding one.

The minutes of the Dallas Membership Meeting, as published in the September 1971 issue of CRL News, were approved and Mr. Reason then read the ACRL election results. He followed this by introducing the new president-elect and section and subsection chairmenelect.

The chair then recognized William R. Pullen, chairman of the ACRL Committee on the Constitution and Bylaws for the required reading of the proposed amendments to the constitution and bylaws. The first of these had been passed by the membership on June 24,1971 , at the annual meeting in Dallas, Texas, and was now being submitted for final approval.

\section{Article IX. Amendments Sec. 1. Constitution}

All proposals for amending the constitution shall be referred to the Board of Directors. A proposed amendment shall become effective when it shall have been approved by a majority of the members of Board present and voting at two consecutive meetings held not less than two months apart, followed by ratification by the members of the Association either by a vote by mail of a majority of the members voting, or by a majority vote of the members present and voting at a meeting of the Association. At least two months written notice shall be given to the Association of the text of the proposed amendment before final consideration.

Mr. Pullen MOved the adoption of this amendment and the measure CARRIED by unanimous vote. The second of the proposed amendments was then read.

\section{Article IX. Mail Votes}

Sec. 1. Mail votes of the membership of the Association may be authorized between meetings by the Board of Directors, provided all members are canvassed simultaneously. Such mail votes shall be conducted under the same requirements as votes at meetings. If no time limit is set, no vote shall be counted unless received within thirty days from the day the text of the matter voted upon was mailed properly addressed to those entitled to vote upon it.

Sec. 2. Mail votes of the Board of Directors may be taken provided they are authorized by the President, President-elect, and Past President, and all voting Board members are canvassed simultaneously. An affirmative vote of three-fourths of the voting Board members shall be required to pass a motion. On each mail vote, each voting Board member shall have the option of voting for or against the motion, to abstain, or to hold for discussion at the next regularly scheduled meeting. Time limits shall be the same as stated above in Sec. 1 of this Article.

Sec. 3. Mail votes of duly constituted committees may be taken by the chairmen of such committees. An affirmative vote of three-fourths of the committee members shall be required to pass the motion. Voting option and time limits shall be the same as stated above in Sec. 2 of this Article.

Mr. Pullen's motion to adopt this proposed amendment received unanimous approval.

Mr. Reason proceeded to introduce Burton E. Lampkin, associate commissioner, Bureau of Libraries and Educational Technology, U.S. Office of Education, who spoke about legislation of interest to academic librarians and about the functions and anticipated activities of his Bureau. Fiscal 1973 priorities outlined by $\mathrm{Mr}$. Lampkin included recruitment and training of minorities; the sharing and utilization of resources for total community import; the continuance of technical assistance for developing institutions such as community, vocational and occupational, and black colleges; cooperation among all types of libraries; and communications.

Mr. Reason next introduced Roy L. Kidman, chairman of the Committee on Academic Status, for a report of the committee's activities. Copies of a Joint Statement on Faculty Status of College and University Librarians (see September 1972 CRL News) were distributed to the members.

Mr. Kidman gave a brief description of the committee work which resulted in the Stan- 
dards for Faculty Status for College and University Librarians (see September 1972 CRL News). He reminded the membership that these standards had been approved at the Dallas Meeting in 1971. They thus became official ACRL Standards and were used as the basis for discussions with the American Association of University Professors and the Association of American Colleges. A joint committee of the three associations had set to work on drafting a statement. He then gave a short history of how the joint statement had evolved, and identified Gerald B. Hubble, Wyman W. Parker, and Luella R. Pollock as the ACRL representatives on the joint committee. The committee held its first meeting in November 1971, and Mr. Kidman attended to give a summation of the ACRL standards and to explain how they had been drafted. He mentioned that the first day of the meeting the discussions were rather tense and there was a great deal of uneasiness, but that on the second day the essential issues were brought forward and a drafting subcommittee was appointed. J. Donald Thomas, at that time the executive secretary, and Wyman Parker represented ACRL. A subcommittee draft of a joint statement was reviewed by the ACRL Committee on Academic Status in April. The Committee on Academic Status met in Chicago and recommended several changes in the document. Mr. Kidman indicated that the crucial issues of concern to the committee were that the joint statement was general in nature as compared with the ACRL Standards and there was no referral in the joint statement to the ACRL Standards. The Committee on Academic Status therefore recommended that the following be added: "The statement on faculty status for librarians approved by ACRL at its Dallas Conference provides details and interpretations for implementation of this document." The draft was sent back to the subcommittee and revision resulted in the document now before the membership. Mr. Kidman pointed out that the Committee on Academic Status planned to make an official recommendation regarding the joint statement to the ACRL Board of Directors at its Thursday meeting and that they now sought comments and recommendations from the mem. bership. He said the motion he was about to make was the opinion of a majority of the committee at this time but that discussion of certain aspects of the statement was desired.

He directed attention to the two paragraphs beginning with line twenty and indicated the rather vague identification of academic librarians who might be eligible for faculty status. This was of concern to some of the committee members as was the lack of a reference to the ACRL document. The proposed addition had not been included. He then MOveD the following.
That the ACRL "Standards for Faculty Status for College and University Librarians," as passed at the ACRL Membership Meeting of June 24, 1971 in Dallas, Texas, be reaffirmed and that the April 26, 1972 Joint Statement on Faculty Status of College and University Librarians of the Association of College and Research $\mathrm{Li}$ braries, the Association of American Colleges, and the American Association of University Professors be endorsed as an effective implementation of many of these standards.

Mr. Reason called for discussion, and E. J. Josey asked to be recognized to present the following.

I move to amend the motion and add to the Joint Statement, page 2, footnote 1, following the word "Absence," "1971 ACRL Standards for Faculty Status."

John Morgan SECONDED the motion and a discussion followed. As a point of order, it was brought out that the motion on the floor was not the document itself and therefore the document could not be amended. Eli Obler agreed that the motion was out of order stating that the membership could not change the joint statement.

R. Dean Galloway said that the purpose of the meeting was to react to the document and to have the membership indicate what needed to be added to, or subtracted from it. $\mathrm{He}$ stressed that this should be kept in mind and that there should not be great concern about parliamentary procedure. Mr. Reason ruled Mr. Josey's motion out of order, and Mr. Josey thereupon MOVED the following substitute motion.

That ACRL adopt the Joint Statement prepared by Representatives of ACRL, AAUP, and AAC and amend the Joint Statement by adding to page 2, footnote 1, following the word "Absence," "1971 Standards for Faculty Status."

After a SECOND by Evert Volkersz, Mr. Reason called for discussion. Mr. Josey stated that he agreed the membership should reaffirm the ACRL Standards and endorse the Joint Statement, but that it was imperative to have the ACRL Standards acknowledged in order to provide guidelines for the implementation of faculty status. The tripartite statement, he pointed out, would go to administrators who would never see the ACRL statement. All he asked for, he continued, was a reference in a footnote.

Mr. Herbert Biblo inquired if this was the first time the Joint Statement had been distributed and indicated that he felt quite ig- 
norant in discussing and evaluating it on such short notice. He asked that in the future such documents be made available at an earlier date.

Mr. Stuart Forth spoke against the substitute motion as he felt it might imperil the entire joint effort. The AAUP and the AAC, he said, had already indicated they were opposed to a specific addition as $\mathrm{Mr}$. Josey proposed. $\mathrm{He}$ pointed out that the AAUP has traditionally developed broad general statements of policy and he cited the joint statement on student rights as an example of a policy statement broad enough so that individual institutions could write up their own codes within an encompassing framework. He said this was the intent of the AAUP, the AAC, and a majority of the members of the Committee on Academic Status. He stated his belief that ACRL needed the support of the other two organizations if its objectives were to be achieved.

Mr. Galloway brought up two matters that troubled him in the joint statement. He said he believed there was prejudice against technical services librarians in the document and suggested that in paragraph four on line twenty-six the word "paragraph" be made plural. This was necessary, he stated, if technical services librarians were to be included in the definition of faculty. He also objected to the inclusion of the statement on library governance. If $\mathrm{Mr}$. Josey's footnote would solve these problems, he said, he was in favor of the substitute motion.

Joan Marshall read from a draft of the joint statement given to her the previous evening by Arthur McAnally, member of the Committee on Academic Status. A line was missing, she said, from the statement which had been distributed. Mr. Kidman remarked that he believed she had seen one of the changes suggested by the Committee on Academic Status which had not been included by the joint committee in the final statement.

Father Brendan Connolly, member of the Committee on Academic Status and a participant in the discussions with the AAUP and AAC, said that he believed lines six and seven clearly covered technical services people. He also stated that it was his strong impression that the representatives of the two organizations did not consider a document like the ACRL Standards appropriate for inclusion in a statement of this type.

Arthur McAnnally also expressed puzzlement about the absence of the sentence referred to by Ms. Marshall. He said the committee was concerned about technical services librarians and, noting that Robert Van Waes, associate secretary of AAUP and a member of the drafting subcommittee was in the audience, he asked that Mr. Van Waes be allowed to speak to this point.

Mr. Van Waes told the membership that
Martha Friedman, a librarian and a member of the AAUP delegation to the joint committee, made it quite clear to the other AAUP representatives that technical services librarians were not to be excluded from anything said in the joint statement. He continued by commenting on the negotiating process and said that in his own view the joint statement did adequately provide guidance to librarians, to faculty members, and to administrators. He recommended the statement to ACRL as a good one which could lead to definite progress in this area.

Allan Dyson spoke against the concept of "faculty status" and opposed the joint statement as twisting definitions to make librarians the teaching faculty they are not. The librarian should instead be seeking his rightful place on campus by working toward a meaningful "academic status," he said, not by aping the faculty.

Evert Volkersz stated his belief that the whole question of academic status needed to be explored much more fully by the membership and he therefore MOVED to postpone further discussion to a time and place at the conference to be announced by the president. E. J. Josey SECONDED the motion, but Arthur Hamlin MOVED the previous question. After a SECOND from the floor the motion to close debate carried.

Mr. Reason then called for the vote on Mr. Josey's substitute motion. It was defeated. The vote on the original motion was then taken and it CARRIED by a majority.

As the next order of business, Mr. Reason called on John R. Beard, chairman of the Ad Hoc Committee for a Membership Levy for an Office for Academic Status. Mr. Beard reported on the special poll conducted via an insert reply card in the May 1972 issue of CRL News. He said that out of a total membership of 10,872 , only 732 responded. This number represented only 6.7 percent of the membership. Of those responding, 149 (20.4 percent) were in favor, 20 (2.7 percent) were opposed to the assessment and believed the office should be funded from the ALA budget; and 116 ( 15.8 percent) were opposed to faculty status and/or the establishment of the office. Mr. Beard stated that since the returns made up a self-selected sample of only a tiny fraction of the membership, they had no meaning and no conclusion could be drawn. The matter rested there.

Mr. Shank then reported on his meeting with the ALA Committee on Program Evaluation and Support. He told the members that many of the ACRL budget requests for the forthcoming year, including funds for staffing of an Office for Academic Status, had not been approved and that the half-time professional assistant position would be eliminated. A reduction in funding for divisional journals would mean a cut in the number of pages available for $C R L$ 


\section{Now, most for the first time, library patrons everywhere can have access to the field of transportation.

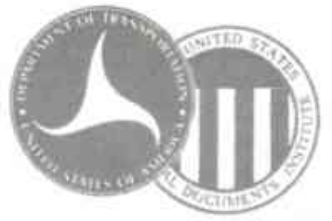

\section{By special arrangement with $t$ the U.S. Historical Document: the Departmental Library's $u$}

For social, economic, and environmental impact, few aspects of modern civilization affect our daily lives as profoundly as Transportation.

During the past fifty years, the U.S. transportation industry has brought phenomenal changes to this country as the value of its goods and services rose to an estimated $20 \%$ of our Gross National Product. The significance of these past changes however, can only be matched by the many challenges which face the industry in the immediate future. How these problems and prospects are met will be major factors in determining not only the future strength of our economy, but also the structure of our society, and the quality of our environment.

Transportation Masterfile 1921-1971 brings together in one collection, descriptive references to the mass of periodical literature on developments in all phases of transportation during this vital half century. Not only does it contain detailed coverage of today's transportation problems, but also it reports on current research projects and advance planning activities from which future solutions may emerge.

\section{SCOPE OF COVERAGE}

As a primary goal of the Department of Transportation is the establishment of a balanced total system for the country, all modes are covered and compared in Transportation Masterfile. These include: highways and motor vehicles, aviation, railroads, inland waterways, ocean shipping, and pipelines, as well as new and experimental and multi-mode systems.

The variety of coverage is indicated by such typical subject headings as: Accidents (by types), Aerial Photography, Air Pollution, Airport Design, Bicycles, Bridges, City Planning, Concrete, Dams, Equipment (types), Expressways, Financing, Federal Aid, Gasoline, and hundreds more.

The collection's variety and international scope are further illustrated in this small sample of titles to current periodicals covered: Acier (Belgium) Air Pollution Control, Australian Road Research, Automotive News, Autostade, (Italy), Aviation Week and Space Technology, Carreteras (Spain), Civil Engincering, Concrete (UK), Electronics Engineering Journal (Canada), Experimental Mechanics, FBI Law Enforcement Bulletin, Human Factors, Indian Roads Congress (India), Ingenieria Civil (Mexico), Journa of American Insurance, Land Economics, Law and Order, Motor, Nation's Cities, Operations Research, Railway Age, Road International (Switzerland), SAE Journal, Seaway Review, State Government, Strasse und Autobahn (Germany), Tax Administrators News, Travaux (France), Urban Land, and Wegen (Netherlands).

Transportation Masterfile 1921-1971 is recommended for purchase by the libraries and information centers of large companies in transportation related industries, as well as government offices, public libraries, and education institutions.

Academic libraries particularly, should find Transportation Masterfile a most valuable self-contained reference tool, in that as its arrangement (chronologically by subject) can save many hours of search effort for both students and librarians. The depth and its size and scope provide comprehensive reference support to such courses as:

Aerospace Technology

Business Administration

Civil Engineering

Earth Sciences

Economics

Ecology

Geography

Government
History
Law
Marketing \& Distribution
Mechanical Engineering
Money and Banking
Petroleum Engineering

Police Science

Political Science

Real Estate

Sociology

Surveying and Mapping

Transportation

Urban Studies

The special emphasis of the collection however, is on the literature covering highways and motor vehicles. This seems appropriate when it is considered that the more than 100 million vehicles now operating in this country (one for every two persons): 1 , account for an overwhelming majority of passenger miles traveled $(88 \%$ of inter-city and $97 \%$ of urban area travel): 2 , are responsible for $94 \%$ of all transportation fatalities (more than 1,000 per week); and 3 . emit $44.5 \%$ of the total pollutants entering the nation's atmosphere.
TR

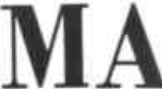

. a mas

technical

... arran

within $S_{L}$

... repre

personn

ON

The con entries is

reels are

All entrit ings and headings Washing

Filming

cameras

parallel

microfil

without

Abbof

for eas entries brousi 
the U.S. Department of Transportation

its Institute announces the dual-media publication of

unique and previously unavailable reference collection ... .

\section{ANSPORTATION}

\section{ISTERFILE, 1921 - 1971}

assive accumulation on microfilm of 700,000 abstracts and annotated references to the al and non-technical periodical literature on all modes of transportation.

anged by Subject under thousands of headings and subheadings (and chronologically Subject)—truly a self-contained reference set.

resents hundreds of thousands of hours of analysis, indexing, and clerical work by inel of DOT and its predecessors over a 50 year period.

\section{MICROFILM}

implete collection of 700,000 abstracts and annotated is contained on $14016 \mathrm{~mm}$ reels or cartridges. $(35 \mathrm{~mm}$ tre available at a slightly higher price).

tries are arranged alphabetically by major subject headind chronologically within subject headings and subngs, just as they are in the Departmental Library in ington, D. C.

ng was carried out in the Library using planetary ras to assure clarity. Images are filmed with the text lel to the length of the reels in order that inexpensive sfilm viewers (not having image rotators) can be used sut turning them on their sides.

fviated contents of each reel are printed on its carton ase of access, and the chronological arrangement of ifs under each subject heading facilitates sequential sing.

\section{IN BOOK FORM}

These two hardcover bibliographic aids are offered without extra charge as part of the collection. They may also be purchased without the microfilm.

Volume I. Transportation Serial Titles. An alphabetical listing of current and non-current periodicals abstracted and indexed in the collection - including names of the issuing offices of U.S. Government serial publications. By itself this book is a most comprehensive catalog of transportationoriented periodicals.

Volume II. Subject Headings in "Transportation Masterfilm, 1921-1971" Part One (Hierarchial). All major headings are arranged alphabetically with the sub-headings listed under them hierarchially as they appear on the microfilm. Reel numbers are given for each. Part Two (Single-Alphabet). All subject terms used in the collection (including various levels of sub-headings) are listed in single alphabet sequence with microfilm reel numbers given for each.

\section{AUTOMATIC UPDATING AVAILABLE IN SEMI-ANNUAL CUMULATIVE SUPPLEMENTS}

To: U.S. Historical Documents Institute, 1647 Wisconsin Ave., N.W., Wash., D.C. 20007

Please record our order at the pre-publication prices shown below for:

$\square$ The Complete Dual-Media Edition of TRANSPORTATION MASTERFILE, $1921-1971$ containing $700,000 \mathrm{ab}$ stracts and annotated entries, arranged by Subject on 140

reels of $16 \mathrm{~mm}$ microfilm - plus two hardcover Index

Volumes _....... $\$ 3,420$

NAME

ADDRESS

CITY STATE
Set of 2 Index Volumes Only _._._._._._. \$105

$\square 1972$ Subscription to Semi-annual Cumulative Supplements (June 30, 1972 and December 31,1972 issues) _..... $\$ 150$

$\square$ Free brochure describing the project in detail 


\section{The Emerging Universe}

\section{Essays on Contemporary Astronomy}

Edited by William C. Saslaw and Kenneth C. Jacobs, University of Virginia. iso pp., illus., charts, index.

New astronomical observations are challenging long-accepted theories, and the recent result is a profound change in our view of the nature of the Universe. In this collection of essays, distinguished astronomers present the emerging picture of our Universe. Each essay summarizes past knowledge of a part of astronomy and astrophysics and then introduces important, usually unsolved, problems. The authors offer their own answers to some of these problems and warn against accepting oversimplified models that may be appealing but poorly justified. The essays provide insight into current trends of cosmological research by demonstrating the questions that astronomers ask, the variety of approaches they use to answer their questions, and some of the positive results of their research.

\section{The Persian Gulf}

\section{Iran's Role}

By Rouhollah K. Ramazani, University of Virginia. $x v, 150$ pp., maps, apps. $\$ 7.50$ With the British departure from the Persian Gulf in 1971 this oil-rich, strategic, and conflict-ridden zone of the Middle East has become a new center of world politics. Iran has aspired to play a leading role in the Persian Gulf since ancient times, but only now does it seem to have the power to do so. The author compares Iran's perspective, capability, and policy with those of the Gulf and non-Gulf Arab states of the Middle East. In examining alternative security arrangements in the Persian Gulf, the author suggests that the kind of role that Iran will be able to play in the area will also depend on the nature and development of Iranian nationalism and on the regional and international environments as these affect the Persian Gulf as a whole.

\section{Legislative History}

\section{Research for the Interpretation of Laws}

By Gwendolyn B. Folsom, University of Virginia. viii, 136 pp., index.

Cloth, \$6.oo; paper, $\$ 2.95$

Legislative history is composed of certain parts, excluding others, of the extensive discussion and documentation which accompany a law in the course of passage by Congress or state legislatures. The function of such history is to aid courts and agencies in finding the intent, scope, and proper application of otherwise general provisions of the laws ultimately adopted. This is the first full description to be published respecting this important and difficult field of legal research. The book first summarizes the general nature of the subject and the highlights of the legislative process, national and state, from which it is derived. Then follows the step-by-step method of research in federal legislative history, which is the core of the book. Special or additional considerations with reference to federal tax laws, constitutional provisions, and treaties conclude the volume. This manual will prove invaluable not only to law students and experienced lawyers, but also to scholars in other fields such as government, history and sociology. 
News. He concluded his remarks by saying he found it somewhat demeaning to go as a division representative to the association and, in essence, beg for our just due. He wondered if we might not explore the budget process, perhaps through the new Interdivisional Committee on Federation, and turn it around to where central headquarters would have to justify itself to the divisions instead of vice-versa.

Mr. Reason announced that a meeting was to be held that evening to discuss the formation of a New England Chapter of ACRL and that all interested nembers were invited to attend. $\mathrm{He}$ concluded by thanking the members and officers, particularly Mr. Shank, for their cooperation during his term of office, and then recognized Jordan M. Scepanski, who Moved a vote of gratitude and appreciation by the membership to Mr. J. Donald Thomas, former ACRL executive secretary, for his dedicated work during four years at headquarters. The motion was SECONDED from the floor and CARRIED by acclamation. Following this action, the meeting was adjourned.

\section{Contracts for Studies of Library Service}

The National Commission on Libraries and Information Science has awarded its first contracts for studies, totaling $\$ 52,000$ for fiscal year 1972 .

Dr. Frederick Burkhardt, chairman of the commission, said that "these contracts are the first steps towards an overall evaluation of library service in this country on all levels. The contracts cover a wide area of concern, and we hope to use these as a base for additional national planning efforts."

The studies to be done include: (1) preliminary investigation of present and potential library and information service needs contracted to the University of California (Berkeley) ; (2) an analysis for social, economic, and technical requirements for libraries and information services, 1975-1980, contracted to Dr. Edwin Parker, professor for Communication Research at Stanford University; (3) a study of funding sources for public libraries to be handled by the Public Administration Service, Chicago, Illinois; and (4) a feasibility study of centralized and regionalized interlibrary loan centers to be done through the Association of Research Libraries, Washington, D.C.

The study for the investigation of present and potential library and information service needs will be done through Charles Bourne who is director of the Institute of Library Re- search and professor, School of Librarianship, University of California, in Berkeley. The comprehensive working paper produced by this study will assist the commission in establishing its priorities in developing national planning for library and informational needs as charged by law. The intent of this study will be to identify needs for service on the part of various "publics" served and to see how the library and information community can best serve those needs.

Some of the major issues to be explored will be a review of the literature relating to the objectives and specifications for post-1975 library services and a survey and assessment of planning, methodology, and techniques that could be helpful. In this study preliminary identification and formulation of tentative specifications will be made for post-1975 information service.

In support of this paper, Dr. Parker, who is professor for Communication Research at Stanford University, shall prepare a comprehensive written document which will identify in specific terms the ways in which United States socialeconomic factors in 1975-1980 and advances in communications and information technology will have impact on the library and information needs of all types of citizens in various information-using roles. Dr. Parker's report will be available to the commission on January 1, 1973.

The Public Administration Service in Chicago has accepted a task for the commission to look at funding sources for public libraries. More than $\$ 800,000,000$ is spent on public libraries and library systems in America and much is known about how the money is spent. Too little is known about its sources. Some libraries obtain revenue from the smallest political areas served (the city, the town, the county), some from the largest (the state). Others obtain money from a combination of sources including municipal, county, region, state, federal, gifts, and endowments. No report of the full scope of fund resources is available, and the commission feels it is now needed.

This study will, Dr. Burkhardt hopes, "let public libraries all over America see where additional funds could be made available and how to get at the money which is so sorely needed by libraries and information centers all over America."

The National Commission on Libraries and Information Science has also contracted with the Association of Research Libraries in Washington for a feasibility study of centralized and regionalized interlibrary loan centers. This particular study will review the current literature, estimate the demand for interlibrary loans in the future, prepare an outline of methodology for a cost study of initial development of central and regional monograph lending centers, establish a professional committee to review recommendations, and to prepare a report to 